\title{
The Concept of Sompek (Wander) of the Buginese Society in Folklore
}

\author{
Amriani $\mathrm{H}^{*}$, Andi Herlina, Murmahyati \\ Balai Bahasa Sulawesi Selatan \\ Makassar, Indonesia \\ *amrianihappe25@gmail.com, andiherlinass@gmail.com, atimurmahyati@yahoo.com
}

\begin{abstract}
The Buginese people are known as people who like to wander both in the archipelago and abroad, this is reflected in their literary works. One of the things that describe the life of the Bugi people as migrants can be found in folklore. This paper aims to describe an overview of sompek (wander), passompek (migrants) and sompereng (places to migrate) depicted in folklore. This paper uses library techniques to collect data and is analyzed descriptively qualitatively to describe the data found in folklore. The results of the research indicate that the factors that caused the Buginese community to migrate were, among others, economic factors and social factors. In the story it is also found that the Buginese migrants always create crowds in their place of migrating and they choose the watershed as their destination for overseas. Another thing that characterizes the Buginese people in migrating is that they continue to build the areas they come, maintain their buginese identity.
\end{abstract}

\section{Keywords-Sompek, folklore, buginese}

\section{INTRODUCTION}

The Buginese society has long had various kinds of literary works, the lagaligo epic is one of the longest works in the world [1]. One part of the story tells the journey of the character of Sawerigading who explores the place with his boat to meet his future wife [2]. The story of a character's journey from one place to another is found in many literary works of the Buginese society. This folklore can legitimize that the Buginese society has the spirit to migrate [3]. Thus, the disclosure on the habit of migrating is interesting because they are not only recorded in history, but have colored the literary works of the Buginese society.

Much research has been written on migratory habits; among them [4]. This article describes the success of Buginese migrants who work together and has a role in the Malay government in the late 17 th to early 18 th centuries. The role of women of Buginese descent in Malay literature in the 19th century [5]. The destination of migration is an imporatnt thing because it can be changing the social status within in the community [6]. The Buginese society knows the terms of sompek (wander) passompek (migrants) and sompereng (place to migrate). These three elements become the identity that is inherent in Buginese person who decides to leave its hometown. There are several beliefs or views that underlie a person decides to migrate, including; mappesona ri dewata rsewae tasalai kampotta taita deceng (surrender to God Almighty, leave your village you will succeed) [7]; ia teppaja kusappa mabbola ri tengga tasik, tenna tappo bombang (which I keep looking for, which is to build a house in the middle of the ocean without being accompanied by a storm) [8]; and pegi monro sore lopie, akkositu tallabu sengngereng (where the boat is dumped off, that's where the anchor is thrown) [9] There are several reasons that encourage a person or group to decide to migrate due to a safety disturbance. This happened when the Wajo Kingdom was attacked by the Bone Kingdom in the 17 th century [10]

The disclosure of the sompek tradition (wander) is closely related to the culture and it encourages the Buginese society in general. Culture has dominated science throughout this century, it not merely in the humanities, but also in natural sciences [11]. The Buginese society cannot be separated from the cultural products that produced as a society that supports certain cultures. This cultural product is a reflection of the existence of the Buginese society. Based on this regard, it can be asserted that the folklore that developed in the Buginese community became one of the sources that revealed their views and thoughts on something. Therefore, the Buginese folklore can become an object capable of revealing the values in its society. It is important to reveal the contents of Buginese folklore to fill the gaps in humanities research. Hence, the researcher attempts to describe the results of research on the concept of sompek (wander) of the Buginese Society in the folklore of Pao-pau Rikadong.

The structure of Levi-Strauss considers that narrative texts such as folklore is equal or similar to sentences based on two things. First, the text is a meaningful whole which can be considered to embody, express the state of mind of an author. Second, a text is a collection of events or parts that together form a story and present various characters in motion. A story is like a sentence, its meaning experiences the acculturation process [12]. 


\section{MethodS}

This paper used a qualitative description method. The data collection techniques were as follows: 1) Looking for myths or events and actions of characters that show certain relationships from the story of the Pau-pau Rikadong; 2) The relation is mapped according to binary opposition as the surface structure of the Pau-pau Rikadong story. The data collected was identified then classified, then analyzed according to the existing problem. The next step was interpretation, then it was described and confirmed. Interviews with migrants were intended to obtain information related to migrating activities. The data source for the Pau-Pau Rikadong story was contained in the book Hikayat Sultanul Injilai and Pau-Pau Rikadong by Abdul Kadir.

\section{RESUltS AND DISCUSSION}

This story begins with the illness of the Luwu king's daughter who has not recovered. Concern happened to the Luwu people. Then, they asked the king for his daughter to leave the Luwu kingdom, or if the king could not, then they would leave Luwu. Finally, the daughter of the king of Luwu came out of Luwu along the river, until finally the group of the Princess of the king of Luwu arrived at an uninhabited place. That is where they start a new life. It was also in that place that the princess's illness was cured due to the treatment from the balar buffalo. The princess was married to the son of the King of Bone, their children who later became kings in the Wajo Kingdom.

\section{A. The Adaptation Reality of Migrants in the Place of Migration}

One of the key of success in migrated place is about the adaptation. Migrants in Kazan showed that their adaptation in large poly-ethnic city takes place succesfully in general because in their new place they maintain their tradition of peaceful interaction and cooperation [13]. It is also practiced by buginese in their migrated place, they keep their tradition including their way to respect their leader in new places.

After going along the river for forty days, the boat docked by the king's daughter in a strange place. They looked around the place. The men then went down to find a suitable location to live in, while the king's daughter was asked to wait on the raft [14].

This episode shows the illustration when the princess and her followers start a new life after leaving Luwu. What they did first was to find a good location, as the residence for the king's daughter and her followers. After finding a suitable place, they build a big house. The treatment of followers to the character of the princess illustrates that the relationship between followers and their leaders. The event of arriving in a new area arises two binary oppositions, among others. It shown on the Table 1 below, which is describe about the relationship between characters
TABLE I. RELATIONSHIP BETWEEN CHARACTERS

\begin{tabular}{|l|l|l|}
\hline King's daughter & Opposition & the follower of king's daughter \\
\hline Palace & & Small house \\
\hline Nearby a big tree & & Behind the big tree \\
\hline
\end{tabular}

The Table 1 above shows relationship between characters. It attributes as a leader are inherent starting from the location, type, shape and size of the house, which is different from the person being led. The word pairs of 'big house' with 'small house' is a marker that indicates the difference between the character of the princess and her followers. Seeing from the size of the building, there are differences, this refers to the identity of the the householder. The comparison between the king's daughter and the follower of the princess continues in the position of residence. "Big tree" is a symbol of strategic society activities. Thus, the opposition "near" and "behind" implies the position where a leader lives in a more strategic place and closer to the center of the crowd. The position of the residence of the princess' followers is behind the center of the crowd.

In order to understand this episode, it requires knowledge of several things related to the Buginese tribe. This part of the story reveals that the reality of the Buginese tribe who have the courage to navigate the waters. They have been used to being in the middle of the sea for days. This resilience is inseparable from their knowledge in the maritime field. By having the knowledge about astronomy, they are able to predict the direction and challenges that will be faced on the journey. This expertise has been proven in lontarak adek-adek Allopingloping bicaranna pabbalue written by Amanna Gappa in the 17 th century. This manuscript regulates the rules in the shipping and trading system [10].

In connection with the journey of the princess, who uses a "boat", it takes a long journey, referring to the transportation that has long been known in Buginese society. The cultural reality which illustrated in this section is that the Buginese society is also the reliable sailor. The Buginese people have also mastered in creating a boat for a long time. Pinisi is one of the traditional boats which is still being developed by the local community in Bulukumba Regency.

The princess' boat was docked in a foreign place. This sentence will be meaningful if it refers to the ideological context of a Buginese migrant, namely pegi monro sore lopie, akkositu tallabu sengereng (where the boat is stranded, that is where the anchor is thrown). This implies the view of the Buginese society which considers that they can go to all places. For the Buginese migrants (sompereng) they do not see the distance, as long as the place is in the form of: tasik akkajang (the sea as they do activities); toddang salo (estuary); tana macommo (loose soil); and the last is pasak maroa (the market which is crowded) [8]. 
The view of the concept of a place which is a source of livelihood has lead to Buginese migrants are capable to live anywhere.

When it is related to the concept of a place for the Buginese society, the diction of "big river" and "big tree" in this story becomes a symbol related to the ideal of migration. This is closely related to the natural resources that can be exploited in these two types of places. "Big river" is described as the estuary, this place can carry out many economic activities such as; fishing, farming, sand mining and transportation. Whereas, "big tree" implies a fertile area, this place enables for the individual to do business in agriculture. This pair of words describes the reality of the economic activities of the Buginese people that they can do in their respective places of residence.

The comparison of the size and position of residence between the princess and her followers is interesting.

When it is linked with the story, it appears that the activities of sompek (wander) are carried out in groups. In social relation of the patron-client, the Buginese society knows about the terms of ponggawa (leader) and joa (led). Both groups have complementary duties and obligations. However, the interesting side is the two groups have identities that differentiate them from one another. One of the dominating identities is a place to live. The house between ponggawa and joa will be different. Until now in several Buginese areas, there are still residences that show this identity. The divison of work in the buginese society in their migrating place show their respect to their leader, the way of migrants behaviour is also an important thing to maintain good relationship with the origin this is written in a research that show about welcoming and unwelcoming immigrants group depended with their behavioral intention [15].

\section{B. Economic Activity}

The table below show about the division of work between male and female in their place of migrating found in the story.

TABLE II. DIVISION OF WORK FOR MALE AND FEMALE

\begin{tabular}{|l|l|l|}
\hline \multicolumn{1}{|c|}{ Male } & \multicolumn{1}{|c|}{ Opposition } & \multicolumn{1}{c|}{ Female } \\
\hline Opening the land & & Harvesting the rice \\
\hline Planting the rice & & Drying the rice \\
\hline
\end{tabular}

The Table 2 above indicates that this comparison is also seen in work activities. Men and women are described for having a clear division of labor in accordance with their respective abilities and expertise. Men have greater power to do tough work such as clearing land and planting rice. Meanwhile, women who are basically patient and careful are assigned tasks in processing rice production. Persistence is one of the keys to the success of the migrants in the place of immigration (passompek). The concept of reso (work ethic) is a spirit for someone who has decided to migrate. They have dared to leave their hometowns and live in a place they do not yet know. To survive, they have to work hard.

\section{Motivational Reality of Migrating}

The event of the character leaved out from its homeland, it occured in the character of the King's princess. She left Luwu when Mapajunge decided to choose his society to stay in Luwu. As a result, the king's daughter went migration. The Luwu society's rejection of the king's daughter was a social problem in the Luwu kingdom. To avoid this case, one of the parties to the conflict, it will leave its hometown. Meanwhile, the character of Arung Maloloe left Bone because he wanted to hunt in other place. He wanted to get the prey. Indirectly, Arung Maloloe left Bone because of economic motivation. The comparison of these events illustrates the reality of a person's motivation to decide migration.

There are several problems that lead to a person or their Buginese society group, among others; want to improve the economic standard of the family; increase family prestige if they have succeed financially elsewhere; kinship relationship, usually someone who has succeeded in one place, the individual will invite another family; ripali (exiled), usually someone leaves its hometown because they suffer from certain illnesses that can endanger others. After recovering, the person can return to its hometown; ripoppangi tanah (considered dead), a person who has committed a serious violation of adat. It is embarrassing the family and society, so that the person is not accepted by the social environment. In order to survive, they have to leave their hometown; and lastly is marontak (chaos occurs) this happens if the safety in the hometown is not guaranteed because of war or the kingdom is ruled by an unjust king, so that someone or a group is willing to leave their hometown. In the case of the princess, it was a ripali event that was exiled, while Arung Maloloe left Bone to show his prestige as a hunter.

The comparison between the events when someone decides to leave a place, especially the homeland, it is shown in the following opposition (Table 3).

TABLE III. COMPARISON OF EVENTS

\begin{tabular}{|l|l|l|}
\hline the king's daughter is sick & Opposition & $\begin{array}{c}\text { Arung Maloloe wants to } \\
\text { hunt }\end{array}$ \\
\hline Nurse, treasure, and servant & & Guard and brave \\
\hline Uninhabited & & Inhabited \\
\hline
\end{tabular}

In Table 3, the comparison between the events that the king's daughter decided to leave her homeland. Before migration, she first prepared to bring her assets, her closest people and her servants. When it is associated with the concept of migrating, this is a description of lekke dapureng (moving to the kitchen). A person who decides to lekke dapureng means that the person and its family will stay somewhere. Meanwhile, the character of Arung Maloloe who left Bone to hunt, therefore, he brought someone who could accompany him during the hunt. The comparison of the two events shows that 
if someone is going to migrate, the individual must have the strength while in the place of migration. The Buginese society symbolizes with tellu cappa (three tips), namely, the cappa kawali (the tip of the keris); cappa lila (tip of the tongue) and cappa katawang (tip of the genitals). These three words imply three main assets, namely: (1) strength (courage, skill or finance); (2) diplomacy; and (3) kinship (marriage).

Finding a new place, it describes the comparison when the Princess of the King and Arung Maloloe and their entourage are in a foreign place for them. This was illustrated by a raft that carried the entourage of the King's Princess arrived at an uninhabited place. Another case with Arung Maloloe's entourage, they had run out of supplies brought from Bone. So that the entourage would not starve, Arung Maloloe ordered Suro to look for food. For the princess' entourage, a new place was found at the end of their journey from Luwu, whereas for Arung Maloloe and his entourage, they found a new place because they wanted to find foodstuffs. The incident of finding a new area illustrates that the view of migrants (passompek) who are ready to live in areas that are already developed or areas that are still left behind.

Further, Suro followed the river, until he found out a village in the middle of the forest. In the middle of the village, there was a palace, Suro went to the palace and met the King's daughter [14]

Suro then followed the river, until he found a village in the middle of the forest. This sentence describes the success of the king's daughter in building the area where she lives. For migrants, the place of migration has become its homeland. In addition to earning a living, they are also attempting to advance the area. This can be done because of its adjacency to the local community. One of the migrants in Ternate told that when he first left in 1965, what he did at that time was to look for older people and ask for a place to stay. During he stayed at the house, he helped to open plantation land, until he was trusted to have the land. Until now the area has developed. The table 4 below show about the opposition between Suro and The King's Princess

TABLE IV. OPPOSITION BETWEEN SURO AND THE KING'S DAUGHTER

\begin{tabular}{|l|l|l|}
\hline \multicolumn{1}{|c|}{ Suro } & \multicolumn{1}{c|}{ Opposition } & \multicolumn{1}{c|}{ King's Daughter } \\
\hline Ordered & & Order \\
\hline Finding food & & Cooking the food \\
\hline
\end{tabular}

The Table 4 above describes about the contradiction between the character of the suro and PR. The character of suro goes to look for food based on the orders given to him. Meanwhile, the PR character orders someone to cook and then gives it to Suro. The opposite opposition between 'order' and 'ordered'. The character of PR as party who has the power to do work using their authority. Meanwhile, the character of suro does the work in accordance with that is assigned to him. On the other hand, the word pairs of 'looking for' food with 'cooking' the food, it indicates that the relationship between patron and client. If a leader is obliged to pay attention to the survival of the people that the leader leads, then someone who is led is also obliged to support the effort.

The principle of 'If someone has been given a drink by someone else, then they are siblings,' this view is always understood and applied by the Buginese society in everyday life. They have a high sense of kinship between each other, especially in the place of migration. Having a mutual respect, mingled and willingness to help among members of the society is always prioritized. The opposition between suro and the princess shows the cultural reality to help each other in difficulties.

\section{CONCLUSION}

The concept of sompek (wander) in Buginese society is reflected in the folklore of Pau-pau Rikadong. Human can live anywhere; this view is considered as the guideline of the Buginese societies so that they have courage to migrate (sompek). The factors that encourage or motivate the Buginese tribe to migrate, it is due to the economic factor and social factor. When deciding to be passompek (migrants), they must have the strength or resilience, especially the work ethic (reso) and the attitude that is able to adapt to the environment of migrating places. While, the person is in the place of immigration (sompereng), the migrants will advance the area as they advance their home region. Although the Buginese migrants have settled in one place of migration, they still preserve their identity of buginese.

\section{REFERENCES}

[1] C. Pelras, Manusia Bugis. Jakarta: Nalar, 2006

[2] Andi Faisal, Diaspora Bugis di Alam Melayu Nusantara. Makassar: Ininnawa, 2010.

[3] A.I. Kusuma, Migrasi dan Orang Bugis. Yogyakarta: Ombak, 2004.

[4] L.Y. Andaya, "The Bugis-Makassar Diaspora," J. Malays. Branch R. Asiat. Soc., vol. 68, no. 119--138, 1995.

[5] B.W. Bandaya, "Studying Women and Gender in Southeast Asia," Int. J. Asian Stud., vol. 4, no. 1, pp. 113--136, 2007.

[6] M. Ivaylo, "Social status and Prestige in condition of transnational migration. ethnographic study among the Albanians from the Republic of Macedonia," Glkasnik Etnogr. Instituta Sanu, vol. 66, no. 3, pp. 617 639, 2018.

[7] A. Sewang, "Serial Syeh Yusuf Pejuang Energik," Pedoman Rakyat, Makassar, p. 5, 2002.

[8] Faisal, "Adaptasi Migrasi Bugis Terhadap Mandar di Kabupaten Mamuju," Makassar.

[9] I.W. Suardi, "Migrasi Bugis dan Madura di Selatan Papua Barat: Perjumpaan Etnis dan Agama di Minoritas.," Intelektual, vol. 6, no. 2, pp. 163-180, 2017.

[10] I.P.G. Suwitha, Perahu Pinisi di Pesisir di Pesisir Bali. Bali: Pustaka Larasan, 2011.

[11] I.N.K. Ratna, Antropologi Sastra: Peranan Unsur-unsur Kebudayaan dalam Proses Kreatif. Yogyakarta: Pustaka Pelajar, 2010.

[12] H.A. Putra, Strukturalisme Levi-Strauss Mitos dan Karya Sastra. Yogyakarta: Kepel, 2013.

[13] G. Stolyarova, "Ethnocultural Behaviour of Migrants in Polyethnic city (Example of the Tajiks of Kazan)," Yearb. Balk. Balt. Stud., vol. 1, no. 1, pp. 145-156, 2018.

[14] K. Mulya, Hikayat Sultanul Injilai dan Pau-Pau Rikadong. Jakarta: Depdiknas, 1985.

[15] L. Froehlich and I. Schulte, "warmth and Competence Streotypes about Immigrant Groups in Germany," PLoS One, vol. 14, no. 9, 2019. 